\title{
PENDIDIKAN KESEHATAN KADER TENTANG PANTANGAN DAN ANJURAN MAKAN SELAMA KEHAMILAN PADA MASYARAKAT PESISIR DESA KARAMPUANG KABUPATEN MAMUJU
}

\section{KADER HEALTH EDUCATION CONCERNING VIEWS AND RECOMMENDED EATING DURING PREGNANCY IN COASTAL COMMUNITIES OF KARAMPUANG VILLAGE, MAMUJU DISTRICT}

\author{
Ashriady ${ }^{\# 1}$, Satriani G. ${ }^{* 2}$, Nurdiana ${ }^{\# 3}$ \\ \#Jurusan Kebidanan,Poltekkes Kemenkes Mamuju \\ Jalan Poros Mamuju - Kalukku KM. 16 Tadui, Kab. Mamuju - Sulawesi Barat \\ 1ashriady.abumuadz@gmail.com
}

\begin{abstract}
Abstrak
Kondisi Desa Karampuang sebagai daerah pesisir memungkinkan masyarakat memenuhi kebutuhan dari protein hewani; ikan, udang, kepiting, cumi dan lain-lain. Berdasarkan Informasi yang diperoleh dari kader Posyandu, masih ada anggapan sebagian dari masyarakat tidak mau mengkonsumsi jenis ikan tertentu karena adanya mitos bahwa akan mempengaruhi kondisi janin setelah lahir. Selain itu, diperoleh informasi bahwa selama kehamilan ditemukan beberapa masyarakat tidak mau mengkonsumsi obat, misalnya tablet Fe karena dianggap akan memperbesar janin dalam kandungan sehingga akan mempersulit proses persalinan. Berdasarkan hal tersebut perlu melakukan pengabdian masyarakat untuk memberikan informasi yang benar kepada masyarakat dengan memanfaatkan peran kader. Metode yang digunakan adalah community relation melalui pertemuan dengan ibu hamil dan pelatihan kader kesehatan. Pertemuan dengan ibu hamil dilakukan dengan suasana yang santai melalui metode curah pendapat (brainstorming). Dalam Pertemuan ini menunjukkan keterbukaan para ibu hamil menyampaikan informasi seputar pantangan dan anjuran makan selama kehamilan. Kegiatan pelatihan kader dilakukan selama sehari, materi yang disusun terkait dengan masalah pantangan dan anjuran makan selama kehamilan, diperoleh dari pertemuan dengan ibu hamil. Materi yang diberikan tentang faktor-faktor yang mempengaruhi kehamilan, gizi pada ibu hamil, dan persiapan persalinan. Selain itu, juga dilakukan demonstrasi dengan menggunakan food model agar dapat meningkatkan pemahaman peserta. Pemberian handout materi dapat menjadi sumber belajar yang lebih selain yang disampaikan oleh pembicara dan dapat dibaca kembali di rumah. Pengabdian masyarakat ini banyak memberikan manfaat bagi ibu hamil dan kader kesehatan. Bentuk nyatanya adalah adanya peningkatan pengetahuan kader dan dan diharapkan dapat terjadi transfer knowledge dari kader kesehatan terhadap ibu hamil dan keluarganya.
\end{abstract}

Kata Kunci : Kehamilan, Ibu Hamil, Pantangan Dan Anjuran Makan

Abstract

The condition of Karampuang Village as a coastal area allows the community to meet the needs of animal protein; fish, shrimp, crab, squid and others. Based on information obtained from Posyandu cadres, there is still an opinion that some people do not want to eat certain types of fish because of a myth that it will affect the condition of the fetus after birth. In addition, information was obtained that during pregnancy it was found that some people did not want to take drugs, for example, Fe tablets because they were thought to enlarge the fetus in the womb, thus complicating the delivery process. Based on this, it is necessary to carry out community service to provide correct information to the community by utilizing the role of cadres. The method used is community relations through meetings with pregnant women and training health cadres. Meetings with pregnant women are carried out in a relaxed atmosphere through the brainstorming method. This meeting showed the openness of pregnant women to convey information about dietary restrictions and recommendations during pregnancy. The cadre training activity was carried out for a day, the materials compiled related to the issue of abstinence and food recommendations during pregnancy were obtained from meetings with pregnant women. The material provided is about factors that affect pregnancy, nutrition in pregnant women, and preparation for delivery. In addition, demonstrations were also conducted using a food model in order to increase participants' understanding. Giving material handouts can be a more learning resource than what is presented by the speaker and can be read back at home. This community service provides many benefits for pregnant women and health cadres. The real form is an increase in knowledge of cadres and it is hoped that there will be a transfer of knowledge from health cadres to pregnant women and their families.

Keywords: Pregnancy, Pregnant Women, Restrictions and Eating Recommendations 


\section{I.PENDAHULUAN}

Pengabdian kepada masyarakat adalah salah satu bentuk kegiatan institusi yang diadakan oleh dosen baik dengan atau tanpa menyertakan mahasiswa, yang ditujukan untuk masyarakat sebagai salah satu Tri Dharma Perguruan Tinggi di samping pendidikan dan penelitian. Dengan dilaksanakannya pengabdian kepada masyarakat baik dalam bentuk pelatihan, pendidikan kesehatan, penerapan hasil penelitian atau dalam bentuk lainnya diharapkan selalu ada keterkaitan bahkan kebersamaan antara Perguruan Tinggi dan masyarakat. Hal ini dapat diartikan sebagai pengamalan IPTEKS (Ilmu Pengetahuan, Teknologi dan Seni) melalui metode ilmiah langsung kepada masyarakat yang membutuhkan, dalam upaya menyukseskan pembangunan dan meningkatkan taraf kehidupan masyarakat.

Hal tersebut sejalan dengan visi Jurusan Kebidanan Poltekkes Kemenkes Mamuju yaitu menjadi institusi pendidikan Kebidanan yang terbaik di Provinsi Sulawesi Barat Tahun 2017 melalui misi menyelenggarakan penelitian dan pengabdian kepada masyarakat dalam mengembangkan dan mengaplikasikan ilmu pengetahuan dan teknologi dalam bidang Kebidanan dan Kesehatan. Tentu hal ini membutuhkan perencanaan yang matang serta dukungan dari semua pihak khususnya staf dosen dan pengelola Jurusan Kebidanan.

Upaya yang akan ditempuh untuk meningkatkan pelaksanaan kegiatan pengabdian kepada masyarakat serta profesionalisme dosen Jurusan Kebidanan Poltekkes Kemenkes Mamuju dalam pengabdian kepada masyarakat adalah dengan kemampuan dan keunggulan yang dimiliki dengan mengembangkan pengabdian masyarakat secara terpadu yang berbasis Health Education. Salah satu program pengabdian kepada masyarakat yang berorientasi pada penyelesaian masalah pada masyarakat yang dikembangkan oleh Unit Penelitian dan Pengabdian Kepada Masyarakat (UP2M) Poltekkes Kemenkes Mamuju diharapkan dapat bersinergi dengan seluruh pemangku kepentingan terkait, dalam rangka meningkatkan keunggulan Poltekkes Kemenkes Mamuju yang semakin kompetitif, terbuka, berbasis keadilan dan bertanggung jawab. Kegiatan pengabdian masyarakat mencakup upaya-upaya peningkatan kualitas sumber daya manusia antara lain dalam hal perluasan wawasan, pengetahuan maupun peningkatan keterampilan yang dilakukan oleh civitas akademika sebagai perwujudan dharma bakti serta wujud kepedulian untuk berperan aktif meningkatkan kesejahteraan dan memberdayakan masyarakat luas.

Status gizi seseorang sangat dipengaruhi oleh makanan yang dikonsumsi (dimakan) dan kondisi kesehatan. Makanan yang dikonsumsi akan diproses dalam tubuh menjadi zat gizi yang diperlukan untuk berbagai kebutuhan tubuh. Pemilihan jenis makanan yang dikonsumsi setiap orang dipengaruhi banyak faktor, seperti kebiasaan makan, tradisi, pemeliharaan kesehatan, daya beli keluarga dan lain-lain (Supariasa, 2012).

Nutrisi selama kehamilan adalah salah satu faktor penting dalam menentukan pertumbuhan janin. Dampaknya adalah berat badan lahir, status nutrisi dari ibu yang sedang hamil juga mempengaruhi angka kematian perinatal. Kalori dibutuhkan untuk pembentukan sel-sel baru, pengaliran makanan dari pembuluh darah ibu ke pembuluh darah janin melalui plasenta, serta pembentukan enzim dan hormon yang mengatur pertumbuhan janin. Kalori diperlukan juga bagi tubuh si ibu itu sendiri untuk dapat berfungsi secara baik (Sulistyoningsih, 2012).

Desa Karampuang Kecamatan Mamuju memiliki keadaan Topografi berbukit-bukit dan berbatu dengan asal-usul genesis yaitu pulau vulkanik. Pemanfaatan lahan yang ada hanya untuk menanam tanaman tegalan dan perkebunan, seperti singkong dan kakao. Umumnya tutupan lahan yang dominan adalah semak belukar dan pohon-pohon keras (lahan kering). Sedangkan morfologi pantai yang ada adalah pantai karang berpasir dan beberapa area bervegetasi mangrove.

Desa Karampuang merupakan pulau yang masih masuk dalam kategori rural dengan sedikit pemukiman dan pemanfaatan lahan yang berskala rumah tangga. Jumlah penduduk di pulau ini mencapai 2.937 jiwa dengan $560 \mathrm{KK}$ sehingga kepadatan penduduk yaitu 461,07 jiwa $/ \mathrm{km}^{2}$. Secara ekonomi, masyarakat Pulau Karampuang hampir dikatakan seratus persen bergantung pada laut dan bertani pada saat tidak ada aktivitas di laut. Umumnya masyarakat menangkap ikan dengan alat tangkap pancing, pukat, tombak dan bubu (Kementerian Kelautan dan Perikanan, 2012).

Kondisi Desa Karampuang sebagai daerah pesisir memungkinkan masyarakat untuk memenuhi kebutuhan mereka dari protein hewani yang berasal dari ikan, udang, kepiting, cumi dan lain-lain. Terlebih pada Ibu Hamil yang membutuhkan asupan protein yang lebih untuk pertumbuhan janinnya. Berkembangnya kepercayaan atau mitos di masyarakat tentang pantangan makan menjadi kendala di Desa tersebut.

Berdasarkan Informasi yang diperoleh dari kader Posyandu di Dusun Karampuang masih ada anggapan sebagian dari masyarakat tidak mau mengkonsumsi jenis ikan tertentu karena adanya mitos bahwa akan mempengaruhi kondisi janin mereka setelah lahir. Selain itu, diperoleh informasi bahwa selama kehamilan ditemukan beberapa 
masyarakat tidak mau mengkonsumsi obat, misalnya tablet Fe karena dianggap akan memperbesar janin dalam kandungan sehingga akan mempersulit proses melahirkan. Hal ini diperparah dengan tidak adanya petugas kesehatan khususnya tenaga bidan yang tinggal menetap di Dusun tersebut sehingga masyarakat masih terkendala dalam penolong persalinan.

Di tempat yang berbeda, kondisi masyarakat pesisir di Kabupaten Mamuju juga menunjukkan perilaku yang sama. Penelitian yang dilakukan di di wilayah kerja Puskesmas Tampa Padang Kecamatan Kalukku menemukan beberapa alasan mengapa ibu hamil pantang terhadap makanan jenis hewani, seperti cumi-cumi, gurita, kepiting dan udang. Alasan tidak mengkonsumsi Udang, karena dikhawatirkan anak akan menyerupai bentuk udang yang bungkuk dan berwarna merah. Tidak boleh mengkonsumsi Kepiting, karena khawatir anak yang lahir hanya memiliki dua jari, seperti Kepiting [4] Rahmaniar, Taslim, \& Baharuddin, 2013.

\section{II.METODE}

Metode pengabdian pada masyarakat yang dilakukan adalah community relation melalui pertemuan dengan ibu hamil dan training atau pelatihan kepada kader kesehatan. Pertemuan dengan ibu hamil dilakukan dengan suasana yang santai melalui metode curah pendapat (brainstorming). Kegiatan pelatihan kader dilakukan dengan pemberian materi yang telah disusun terkait dengan masalah pantangan dan anjuran makan selama kehamilan, diperoleh dari pertemuan dengan ibu hamil. Materi yang diberikan yaitu tentang faktor-faktor yang mempengaruhi kehamilan, gizi pada ibu hamil, dan persiapan persalinan. Selain pemberian materi juga dilakukan demonstrasi dengan menggunakan food model agar dapat meningkatkan pemahaman peserta.

\section{III.HASIL DAN PEMBAHASAN}

Kegiatan Pengabdian Masyarakat (Pengabmas) bertajuk pendidikan kesehatan tentang pantangan dan anjuran makan selama kehamilan pada masyarakat Desa Karampuang Kecamatan Mamuju, dihadiri oleh Ibu hamil dan kader kesehatan di Desa ini dengan antusias. Kegiatan ini berlangsung mulai tanggal 25 Oktober - 09 November 2017, dengan 2 bentuk kegiatan yaitu diawali melalui pertemuan dengan ibu hamil untuk menggali informasi tentang pantangan dan anjuran makan selama kehamilan, kemudian dilanjutkan dengan pelatihan sehari untuk kader kesehatan tentang pantangan dan anjuran makan selama kehamilan.

Pelatihan kader dimaksudkan agar masalah yang ditemukan terkait dengan pantangan dan anjuran makan selama kehamilan mampu diberikan solusi melalui peningkatan pengetahuan kader. Hasil pelatihan di evalusi dengan melihat peran serta kader dalam menyampaikan materi pelatihan yang diterimanya kepada masyarakat khususnya ibu hamil.
Dalam kegiatan pengabmas ini, selain dibekali materi tentang pantangan dan anjuran makan selama kehamilan, kader juga dibekali poster untuk memudahkan penyampaian informasi kepada masyarakat.

\section{Pertemuan dengan Ibu Hamil}

Kegiatan pertemuan dengan ibu hamil dilakukan dengan suasana yang santai melalui metode curah pendapat (brainstorming) sehingga masyarakat lebih terbuka mengungkapkan masalahnya terkait pantangan dan anjuran makan selama kehamilan. Metode brainstorming adalah proses penyampaian sebanyak-banyaknya gagasan pemecahan suatu masalah secara bebas, terbuka, dan tanpa ada kritik terhadap gagasan-gagasan yang muncul. Tujuan curah pendapat adalah untuk membuat kompilasi (kumpulan) pendapat, informasi, pengalaman semua peserta yang sama atau berbeda. Hasilnya kemudian dijadikan peta informasi, peta pengalaman, atau peta gagasan (mindmap) untuk menjadi pembelajaran bersama [2] Benanza, Pitoewas, \& Yanzi, 2014

Pertemuan dengan ibu hamil berlangsung pada tanggal 8 November 2017 bertempat di balai Desa Karampuang, mulai pukul 09.00 - 12.00 Wita, yang dihadiri 15 orang ibu hamil. Dalam Pertemuan ini menunjukkan keterbukaan para ibu hamil menyampaikan informasi seputar pantangan dan anjuran makan selama kehamilan yang selama ini mereka lakukan. Selain itu, mereka juga mengutarakan alasan dilakukannya hal tersebut. Informasi tersebut dapat diuraikan dalam tabel berikut ini:

\section{Tabel 1. Pantangan Makan dan Perilaku selama Kehamilan di Desa Karampuang Kecamatan Mamuju Tahun 2017}

\begin{tabular}{|c|c|c|}
\hline No. & $\begin{array}{c}\text { Pantangan } \\
\text { Makan/Perilaku }\end{array}$ & Alasan \\
\hline 1. & $\begin{array}{l}\text { Larangan makan cumi dan } \\
\text { gurita }\end{array}$ & Plasenta melengket \\
\hline 2. & Larangan makan jeruk & Ketuban merembes \\
\hline 3. & Tidak makan buah nenas & $\begin{array}{l}\text { Korengan pada anak } \\
\text { (gatal-gatal) }\end{array}$ \\
\hline 4. & Tidak makan durian & $\begin{array}{l}\text { Anak panas, kulitnya } \\
\text { melepuh jika anaknya } \\
\text { lahir }\end{array}$ \\
\hline 5. & $\begin{array}{l}\text { Tidak makan udang dan } \\
\text { kepiting }\end{array}$ & $\begin{array}{l}\text { Bayinya susah lahir, } \\
\text { menempel }\end{array}$ \\
\hline 6. & $\begin{array}{l}\text { Larangan makan } \\
\text { cakalang }\end{array}$ & $\begin{array}{lr}\text { Banyak } & \text { darah, } \\
\text { perdarahan } & \text { saat } \\
\text { melahirkan } & \end{array}$ \\
\hline 7. & Larangan makan telur & $\begin{array}{ll}\text { Anaknya } & \text { akan } \\
\text { mengalami luka } & \end{array}$ \\
\hline 8. & Tidak makan pisang & $\begin{array}{l}\text { Bayinya akan sakit } \\
\text { perut }\end{array}$ \\
\hline 9. & Larangan makan cabe (pedis) & $\begin{array}{l}\text { Kulitnya } \\
\text { (melepuh) }\end{array}$ \\
\hline 10. & Larangan makan ikan manori & $\begin{array}{l}\text { Kulit anak akan } \\
\text { mengalami luka }\end{array}$ \\
\hline 11. & Larangan minum es & $\begin{array}{l}\text { Anaknya besar } \\
\text { sehingga susah lahir }\end{array}$ \\
\hline 12. & $\begin{array}{l}\text { Larangan mempersiapkan } \\
\text { kelahiran (baju, celana, dll) }\end{array}$ & $\begin{array}{l}\text { Anaknya akan } \\
\text { meninggal }\end{array}$ \\
\hline
\end{tabular}




\begin{tabular}{|c|c|c|}
\hline & $\begin{array}{l}\text { Larangan melilit handuk di } \\
\text { leher }\end{array}$ & $\begin{array}{l}\text { Menghindari lilitan tali } \\
\text { pusat }\end{array}$ \\
\hline & $\begin{array}{l}\text { Larangan mengkonsumsi } \\
\text { tablet tambah darah }\end{array}$ & $\begin{array}{l}\text { Ibunya muntah, anak } \\
\text { besar }\end{array}$ \\
\hline 15. & Tidak boleh tidur pagi & $\begin{array}{l}\text { Badan ibu akan } \\
\text { bengkak }\end{array}$ \\
\hline 6. & Larangan keluar sore & $\begin{array}{l}\text { Akan bertemu dengan } \\
\text { syaitan }\end{array}$ \\
\hline 7. & $\begin{array}{l}\text { Larangan potong rambut } \\
\text { selama hamil muda }\end{array}$ & $\begin{array}{l}\text { Anaknya akan lahir } \\
\text { cacat }\end{array}$ \\
\hline 18. & $\begin{array}{l}\text { Larangan bagi suami agar } \\
\text { tidak terkena hujan gerimis } \\
\text { atau air jemuran }\end{array}$ & $\begin{array}{l}\text { Terjadi } \\
\text { merembes }\end{array}$ \\
\hline 19. & $\begin{array}{l}\text { Larangan suami untuk } \\
\text { selingkuh }\end{array}$ & $\begin{array}{l}\text { Bayi memiliki banyak } \\
\text { bulu }\end{array}$ \\
\hline & $\begin{array}{l}\text { Suami dilarang membuat } \\
\text { penjepit ikan }\end{array}$ & Bayi akan terjepit \\
\hline
\end{tabular}

Tabel 2. Anjuran Makan dan Perilaku selama Kehamilan di Desa Karampuang Kecamatan Mamuju Tahun 2017

\begin{tabular}{lll}
\hline No. & \multicolumn{1}{c}{$\begin{array}{c}\text { Anjuran } \\
\text { Makan/Perilaku }\end{array}$} & \multicolumn{1}{c}{ Alasan } \\
\hline 1. & $\begin{array}{l}\text { Makan sayur pepaya } \\
\text { Makan kacang tanah } \\
\text { goreng }\end{array}$ & $\begin{array}{l}\text { ASI menjadi lancar } \\
\text { Memperlancar ASI }\end{array}$ \\
3. & $\begin{array}{l}\text { Konsumsi minyak kelapa } \\
\text { asli di trisemester III }\end{array}$ & Mempermudah kelahiran \\
4. & $\begin{array}{l}\text { Konsumsi daun serei } \\
\text { Minum air kelapa }\end{array}$ & $\begin{array}{l}\text { Anak lahir dalam kondisi } \\
\text { bersih }\end{array}$ \\
5. & $\begin{array}{l}\text { Minum } \\
\text { 6. }\end{array} \quad \begin{array}{l}\text { Pakaian suami dari laut } \\
\text { diperas di atas kepala ibu } \\
\text { hamil } \\
\text { Ibu menjaga higiene } \\
\text { perorangan }\end{array}$ & Obat ngidam \\
\hline
\end{tabular}

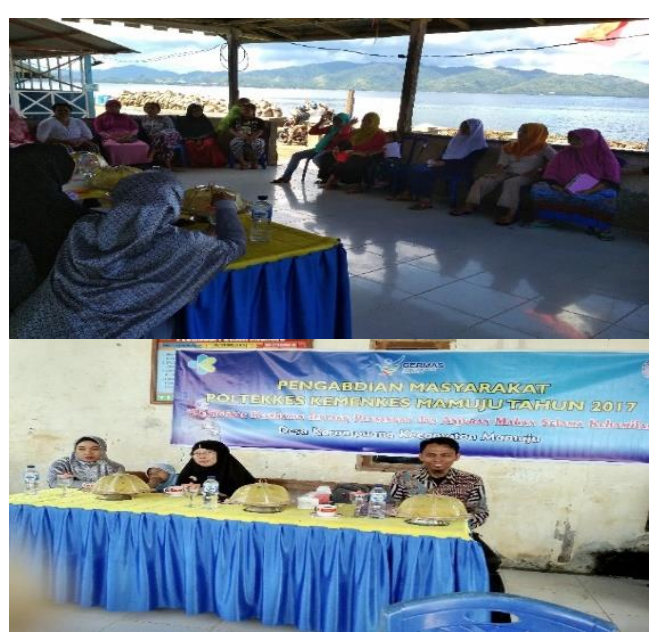

Gambar 1: Curah Pendapat dengan Ibu Hamil

\section{Pelatihan Kader}

Menurut Tanjung (2003), pelatihan merupakan suatu proses belajar mengajar terhadap pengetahuan dan keterampilan tertentu serta sikap agar peserta semakin terampil dan mampu melaksanakan tanggung jawabnya dengan semakin baik, sesuai dengan standar. Pelatihan merupakan salah satu usaha untuk mengembangkan SDM, terutama dalam hal pengetahuan (knowledge), kemampuan (ability), keahlian (skill) dan sikap (attitude) (Ardiansyah, [1] Musadieq, \& Ruhana, 2014)

Menurut Tanjung (2003), pelatihan merupakan suatu proses belajar mengajar terhadap pengetahuan dan keterampilan tertentu serta sikap agar peserta semakin terampil dan mampu melaksanakan tanggung jawabnya dengan semakin baik, sesuai dengan standar. Pelatihan merupakan salah satu usaha untuk mengembangkan SDM, terutama dalam hal pengetahuan (knowledge), kemampuan (ability), keahlian (skill) dan sikap (attitude) [1] Ardiansyah, Musadieq, \& Ruhana, 2014

Tabel 3. Daftar Materi Pelatihan Kader Tentang Pantangan dan Anjuran Makan Selama Kehamilan di Desa Karampuang Kecamatan Mamuju Tahun 2017

\begin{tabular}{|c|c|c|c|c|}
\hline No. & Materi & Waktu & Pemateri & $\begin{array}{c}\text { Metode/ } \\
\text { Alat dan } \\
\text { Bahan }\end{array}$ \\
\hline 1. & $\begin{array}{l}\text { Faktor-faktor } \\
\text { yang } \\
\text { mempengaruhi } \\
\text { kehamilan }\end{array}$ & $\begin{array}{c}09.00- \\
10.00 \\
\text { Wita }\end{array}$ & $\begin{array}{l}\text { Ashriady, } \\
\text { M.Kes }\end{array}$ & $\begin{array}{c}\text { CTJ/ } \\
\text { Handout } \\
\text { materi }\end{array}$ \\
\hline 2. & $\begin{array}{l}\text { Gizi pada ibu } \\
\text { hamil }\end{array}$ & $\begin{array}{c}10.00- \\
11.00 \\
\text { Wita }\end{array}$ & $\begin{array}{l}\text { Nurdiana, } \\
\text { S.ST., } \\
\text { M.Kes }\end{array}$ & $\begin{array}{l}\text { Demonstrasi/ } \\
\text { Food model }\end{array}$ \\
\hline 3. & $\begin{array}{l}\text { Persiapan } \\
\text { persalinan }\end{array}$ & $\begin{array}{c}11.00- \\
12.00 \\
\text { Wita }\end{array}$ & $\begin{array}{l}\text { Satriani } \\
\text { G. S.ST., } \\
\text { M.Kes }\end{array}$ & $\begin{array}{c}\text { CTJ/ } \\
\text { Handout } \\
\text { materi }\end{array}$ \\
\hline
\end{tabular}

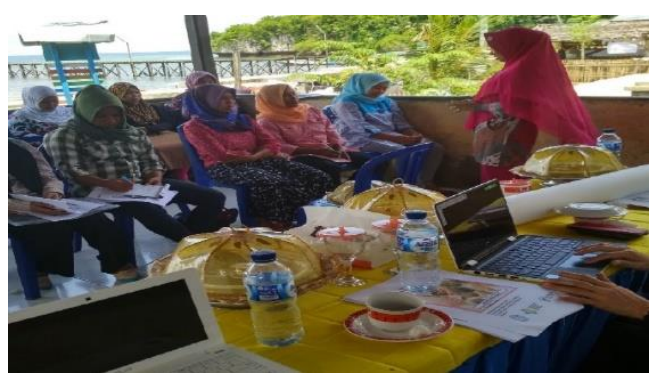




\section{DAFTAR PUSTAKA}

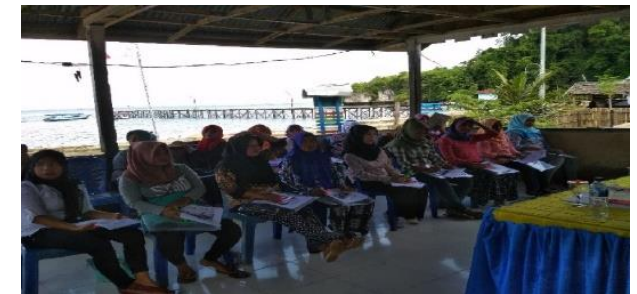

Gambar 2: Pemateri sedang Memberikan Pelatihan kepada Kader

Kegiatan pelatihan kader dilakukan selama sehari dengan materi yang disusun berdasarkan masalah anjuran dan pantangan makan selama kehamilan yang diperoleh pada pertemuan dengan ibu hamil. Kegiatan pelatihan berlangsung pada tanggal 9 November 2017 atau sehari setelah pertemuan dengan ibu hamil yang juga bertempat di Balai Desa Karampuang. Adapun rincian jadwal materi yang diberikan dalam pelatihan kader tersebut dapat dilihat dalam tabel 3 .

\section{SIMPULAN DAN SARAN}

Pengabdian masyarakat ini banyak memberikan manfaat bagi kader kesehatan dan ibu hamil. Bentuk nyatanya adalah adanya peningkatan pengetahuan kader dan keterbukaan ibu hamil.

Setelah terjadi peningkatan pengetahuan diharapkan tumbuhnya perilaku yang benar tentang pantangan dan anjuran makan selama kehamilan. Peran kader kesehatan diharapkan dapat mengaplikasikan ilmu yang diterima dalam training (pelatihan) dalam kehidupan sehari-hari dan diharapkan dapat terjadi transfer knowledge (transfer ilmu pengetahuan) atau bahkan terjadi transformasi (melakukan sebelum menyampaikan) dari kader kesehatan terhadap ibu hamil dan keluarganya.

Diperlukan metode yang tepat di dalam penggalian masalah kesehatan di masyarakat, metode curah pendapat dapat menjadi alternatif dengan melihat hasil yang diperoleh dari pertemuan dengan Ibu Hamil di Desa Karampuang yang membahas tentang pantangan dan anjuran makan selama kehamilan. Diperlukan pendampingan dari petugas kesehatan khususnya bidan terhadap kader yang telah diberikan pelatihan sehingga proses transfer knowledge (transfer ilmu pengetahuan) dari kader kesehatan terhadap ibu hamil dan keluarganya dapat berjalan sebagaimana yang diharapkan.
[1] Ardiansyah, Musadieq, M. Al, \& Ruhana, I. (2014). Pengaruh Pelatihan terhadap Kompetensi dan Kinerja (Studi pada Karyawan Departemen Research and Development PT. Gatra Mapan Malang). Jurnal Administrasi Bisnis (JAB), 9 (1). Retrieved from http://download.portalgaruda.org/article.php?Article=189919 \&val $=6468 \&$ title $=$

[2] Benanza, R. M., Pitoewas, B., \& Yanzi, H. (2014). Hubungan Penerapan Metode Pembelajaran Brainstorming terhadap Kemampuan Berpikir Kritis Siswa. Jurnal Kultur Demokrasi, 2 (2). Retrieved from http://jurnal.fkip.unila.ac.id/ index.php/JKD/article/view/4286/2682

[3] Kementerian Kelautan dan Perikanan. (2012). Direktori PulauPulau Kecil Indonesia. Retrieved January 10, 2017, from http://www.ppk-kp3k.kkp. go.id/ direktori-pulau/index. php/public_c/ pulau_info/388.

[4] Rahmaniar, A., Taslim, N. A., \& Baharuddin, B. (2013). Factors related to maternal chronic energy deficiency in Tampa Padang, Mamuju Regency, West Sulawesi. Media Gizi Masyarakat Indonesia, 2(2), 98-103.

[5] Sulistyoningsih, H. (2012). Gizi Untuk Kesehatan Ibu Dan Anak. Jakarta: Graha Ilmu.

[6] Supariasa, I. D. N. (2012). Pendidikan dan Konsultasi Gizi. Jakarta: EGC. 